\title{
Effects of Lime and Compost on Acidic Soil Amelioration and Grain Yield of Maize at Jimma, Southwestern Ethiopia
}

\author{
Jafer Dawid \\ Ethiopian Institute of Agricultural Research, Jimma Agricultural Research Centre, Jimma, Ethiopia
}

\begin{abstract}
Maize is the third important cereal crop globally after wheat and rice. Though it is consumed in all regions of Ethiopia, the crop is used as stable food in western and south western part of the country. However, Soil acidity and nutrients depletion are serious limitations in maize productivity improvement. Now a day, increasing maize production through expansion of cultivable land is no more possible. Productivity of the crop on less fertile acidic soils can be improved by integrated use of soil amendments like lime, compost as well as farm yard manure and proper fertilizer management. In Ethiopia, integrated approach of soil fertility management is attractive prime importance these days. The objective of this study is to evaluate effects of manure (FYM),compost, and their interactions with lime and inorganic fertilizers on soil properties and maize productivity. The experiment was conducted for consecutive cropping seasons 2010-2013 at Melko Jima Agricultural Research Center. The Center is found in South Western Ethiopia; in Oromiya National Regional State and located at $7^{\circ} 40^{\prime} 47^{\prime \prime} \mathrm{N}$ latitude and $36^{\circ} 49^{\prime} 47^{\prime \prime} \mathrm{E}$ longitude. The mean maximum and minimum temperature of the Center are 26.2 and $11.3^{\circ} \mathrm{C}$ respectively. The elevation of the Center is $1,753 \mathrm{~m}$ above sea level and it receives $1,529.5 \mathrm{~mm}$ average annual Rainfall. The design was RCB design with three replications. Combinations of organic, inorganic fertilizers and lime significantly $(\mathrm{P} \leq 0.05)$ influenced maize grain yield in all cropping seasons. The result also revealed that in the first cropping season, recommended NP gave significantly higher yield than other combinations. On the other hand, recommended NP + recommended lime resulted in significantly higher grain yield than other combinations in 2011 and 2012 cropping seasons. It is shown that application of organic, inorganic fertilizers and lime significantly affected soil properties such as $\mathrm{pH}$, exchangeable acidity, available phosphorus organic carbon content and cation exchange capacity. Accordingly, the use of compost alone, compost and lime significantly improved soil reaction in relation to other combinations. However the use of $\mathrm{N}$ and $\mathrm{P}$ and its combinations with organic fertilizer and lime did not improve soil $\mathrm{pH}$. This indicates the soil acidity aggravate effect of ammoniac fertilizes. Compost, together $\mathrm{N}$ and $\mathrm{P}$, compost with lime as well as half of compost, lime and recommended $\mathrm{N}$ and P significantly lowered exchangeable acidity of the soil. The use of compost alone and as well as compost and lime simultaneously significantly increased available $\mathrm{P}$ in soil solution relative to other combinations. It was also observed that application of compost alone and simultaneously with lime improved CEC and organic carbon stack of the soil. Generally, the use of integrated compost, manure, lime and in directly and indirect improving soil chemical and physical properties. provide significant quantities of available nitrogen, $\mathrm{P}, \mathrm{Mo}$ and $\mathrm{B}$, and more favorable conditions for microbial mediated reactions. Integrate use of lime, organic nutrient sources and inorganic fertilizers are beneficial in improving maize productivity and ameliorating properties of acid soil.
\end{abstract}

Keywords: Compost, Exchangeable acidity, FYM, Lime, P fertilizer, Soil pH

DOI: $10.7176 / \mathrm{JNSR} / 12-3-03$

Publication date: February $28^{\text {th }} 2021$

\section{Introduction}

Maize is the third important cereal crop globally after wheat and rice (FAO, 2014). Though it is consumed in all regions of Ethiopia, the crop is used as stable food in western and south western part of the country. However, Soil acidity and nutrients depletion are serious limitations in maize productivity improvement. Now a day, increasing maize production through expansion of cultivable land is no more possible (Tolessa et al., 2001). Productivity of the crop on less fertile acidic soils can be improved by integrated use of soil amendments like lime, compost as well as farm yard manure and proper fertilizer management (Asrat et al., 2014).

A complementary use of organic manures and chemical fertilizers has proven to be the best soil fertility management strategy in the tropics (Ayodele and Shittu, 2014). Enhanced soil organic matter increases soil aggregation and water-holding capacity, provides source of nutrients, and reduces $\mathrm{P}$ fixation, toxicities of $\mathrm{Al}$ and $\mathrm{Mn}$, and leaching of nutrients (Fageria and Baligar, 2008).

The grain yield and nutrient use efficiency was better under integrated nutrient management than that expected from mere additive effects of sole applications (Amoah et al., 2012). Integrated use of organic residues and mineral fertilizers reduced the cost of mineral fertilizer need by 25\% (Bokhtiar and Sakurai, 2005) and by up to $50 \%$ (Kiani et al., 2005). Management methods that reduce the use of agricultural chemicals are also needed to avoid adverse environment impacts (Bilalis et al., 2009). It is therefore important to investigate cropping and nutrient management systems to optimize the use of all nutrient sources including fertilizers, organic manures, soil reserves and biological nitrogen fixation for the maintenance of soil fertility and crop productivity. 
Soil acidity is among the major land degradation problems, which affects $\sim 50 \%$ of the world's potentially arable soils (Kochian et al., 2004). Soil acidity and associated low nutrient availability are key constraints to crop production in acidic soils, mainly Nitisols of Ethiopian highlands (Zeleke et al., 2010). Haile et al. (2017) estimated that $\sim 43 \%$ of the Ethiopian cultivated land is affected by soil acidity). Integrated soil fertility management (ISFM) is one of the approaches to manage and improve soil health and fertility status (Agegnehu and Amede, 2017; Fageria and Baligar, 1997). ISFM is one of the components of the management of acid soils. Farmyard manure (FYM) and crop residues are among organic plant nutrient sources, which could ameliorate the physical and chemical properties of soils Proper combined application of liming and composting the acid soils has the potential of contributing to an overall increase of maize yields cultivated in such soils because of reducing exchangeable acidity and increasing $\mathrm{pH}$ and soil fertility Onwonga et al. (2008). Therefore, the practice of well-planned and execution of liming and composting is fundamental to improve soil fertility and for increasing yields on acid soils. This in turn helps to reduce crop production risks associated with soil acidity, as both of them promote nutrients use efficiency. However, information on the low soil fertility and extent of soil acidity problems on maize production and their amendments through lime and compost to reclaim this soil in different integration form is not well documented. Thus, this study was conducted with the aim of finding out the effects of farmyard manure , compost and their interactions with lime and inorganic fertilizers on maize productivity and properties of acid soils in south western Ethiopia.

\section{Materials and Methods}

The study was conducted at Jimma Agricultural Research Center. The Center is found in the southwestern part of the country in Oromia National Regional State. It is located at coordinates of $7046^{\text {ee }} \mathrm{N}$ latitude and $3600, \mathrm{E}$ longitudes at an elevation 1750 meters above sea level. The center receives an average annual rainfall of $1529 \mathrm{~mm}$ with the mean maximum and minimum temperatures of 25 and $11.20 \mathrm{C}$, respectively. The predominant soil of the center is Eutric Nitosols with an average pH of 5.2 (Paulos,1994).

\section{Experimental design and procedure}

The treatments consisted of control (without amendment), compost, farmyard manure (FYM), mineral fertilizers and their combination as follows: (1) Recommended NP mineral fertilizers N 92 and P2O5 46 kg ha-1 (2) Compost based on mineral $\mathrm{N}$ fertilizer equivalency (3) FYM based on mineral $\mathrm{N}$ fertilizer based on mineral $\mathrm{N}$ fertilizer equivalency (4) $50 \%$ recommended $\mathrm{N}$ from $\mathrm{FYM}+46$ and $23 \mathrm{~kg} \mathrm{~N}$ and P2O5 ha-1 (5) $50 \%$ recommended $\mathrm{N}$ from compost + N46 and P2O5 $23 \mathrm{~kg}$ ha-1 mineral fertilizer (6) Recommended N from FYM + $1440 \mathrm{~kg}$ ha-1 Lime (7) Compost based on mineral N fertilizer equivalency + 1440 Lime kg ha-1 (8) Recommended NP N 92 and P2O5 $46 \mathrm{~kg}$ ha-1 + 1440 Lime kg ha-1 (9) 50\% recommended N from FYM + N 46 and P2O5 $23 \mathrm{~kg}$ ha-1 + $1440 \mathrm{~kg}$ ha1 Lime ( 10) 50\% recommended N from compost + N 46 and P2O5 $23 \mathrm{~kg}$ ha-1 $+720 \mathrm{~kg}$ ha-1 lime (11) control without any amendments. The experiment was conducted for four consecutive cropping seasons $(2010-2013)$ using randomized complete block design with three replications. The different rates of compost and FYM were applied based on inorganic $\mathrm{N}$ equivalency that was calculated on dry weight basis. Each rate was applied to the respective experimental unit one month before sowing maize seeds and incorporated manually in the upper 15-20 $\mathrm{cm}$ soil depth. Compost, FYM and lime were manually uniformly broadcasted to the experimental plots at once in the first year and incorporated into the soil one month before planting. Hybrid maize, $\mathrm{BH} 660$, seeds were sown in the month of April/May. Two seeds per hill in rows were planted at a spacing of $80 \mathrm{~cm}$ between rows and 50 $\mathrm{cm}$ between plants. Lime treatment having a calcium carbonate equivalent (acid neutralizing value) value of $102 \%$ was calculated based on the soil exchangeable acidity of the experimental site using the following formula $L R \mathrm{CaCO}_{3} \mathrm{~kg} \mathrm{ha}=\mathrm{EA}(\mathrm{cmol} \mathrm{kg}$ of soil $) * 0.15 \mathrm{~m} * 10^{4} \mathrm{~m}^{2 *} \mathrm{BD}\left(\mathrm{Mg} / \mathrm{m}^{3}\right) * 1000$

$$
2000
$$

Where LR $=$ Lime requirement of the soil based on exchangeable acidity and EA =Exchangeable acidity. The different rates of mineral $\mathrm{N}$ fertilizers were applied as urea twice with half dose at planting and the remaining half at 30 to 40 days after emergence (knee height stage). Phosphorus was applied as in the form of TSP (46\% P2O5) in the respective experimental plots at planting. Half of the Urea and the whole TSP were applied at side dressing and mixed with the soil manually. All other cultural practices were applied uniformly to all experimental units as per the requirement of the crop.

\section{Sampling and analysis}

Composite soil samples were collected using an auger at $0-20 \mathrm{~cm}$ depth from different places in the experimental field before planting. After harvesting, soil samples were collected from each experimental plot. The collected soil samples were air dried in wooden tray, ground and sieved to pass through a $2 \mathrm{~mm}$ sieve. The samples were analyzed for soil $\mathrm{pH}$, exchangeable acidity, available $\mathrm{P}$, cation exchange capacity and organic carbon. Soil $\mathrm{pH}$ was determined using digital $\mathrm{pH}$ meter in 1:2.5(H2O) soil to solution ratio (Van Reedwijk, 1992). Exchangeable acidity was determined by extracting the samples with $1 \mathrm{M} \mathrm{KCl}$ solution and titrating with $\mathrm{NaOH}$ as described by McLean 
(1965). Cation exchange capacity of the soil was determined according to Chapman (1966). Organic carbon was determined following the wet digestion method (Walkley and Black, 1934). Organic matter content was calculated by multiplying the percent OC by 1.724. Available P was determined with Bray II (Bray and Kurtz, 1945) extraction methods. One kilogram of a well decomposed compost and FYM was sampled separately from their respective decomposed pile after mixing the heap of the different organic sources. Then, the samples were oven dried at $1050 \mathrm{C}$ for 24 hours to a constant weight. The moisture content of the samples was determined gravimetrically and this was used for determination of the amount of organic sources that was applied in the respective experimental units based on mineral $\mathrm{N}$ equivalency.

\section{Data analysis}

Yield and soil data were subjected to analysis of variance using SAS statistical software (SAS version 9.1, 2008). Means were separated using Duncan ${ }^{\text {ee }}$ Multiple Range Test whenever the „Fee test was significant.

\section{Result and Discussion}

Some of the physical and chemical characteristics of the soil samples before experiment presented in Table1. The initial soil characterizations results for soil of the study area was sandy clay textural class of soil., the soil type is among dominant acidic soils type Nitisols in southwest (FAO classification). The soil pH value for cultivated land was 4.63 which is very strongly acidic,according to soil reaction categories described in Foth and Ellis (1977). This is because of the high precipitation, which causes large leaching of bases down the soil profile (Foth and Ellis, 1997).Exchangeable acidity values for cultivated land $1.28 \mathrm{cmole}(+) / \mathrm{kg})$. This show that intensive cultivation and application of inorganic fertilizers leads to the higher exchangeable acidity content under the crop field (Wakene Negassa, 2001). The CEC values of the soils in the study area was $(20.5 \mathrm{cmol}(+) / \mathrm{kg}) \mathrm{medium}$ According to Landon (1991).Total nitrogen $0.11 \%$ and the values were in the low range according to Brook (1983). The available phosphorus content of soil samples of the study area $0.83 \mathrm{ppm}$, which is far below the critical soil test value for available P (Jones, 2001; Brook, 1983). The available P values are also below the critical P value established for some Ethiopian soils (Tekalign Mamo and Haque, 1991). Exchangeable potassium $1.41 \mathrm{me} / 100 \mathrm{~g}$ of soil which is above the critical value of $80 \mathrm{ppm}$ considered for plant growth (Farina, 1999). The organic matter content of the cultivated land is 2.15 percent was medium The soils are also generally low in exchangeable Ca, $\mathrm{Na}, \mathrm{Mg}$ values.

Table 1. Initial soil physical and chemical properties of the experimental sites before planting

\begin{tabular}{|c|c|c|c|c|c|c|c|c|c|c|c|c|}
\hline \multirow[b]{2}{*}{$\begin{array}{l}\text { pH } \\
(\mathrm{H} 20) \\
1: 2.5\end{array}$} & \multirow[t]{2}{*}{$\% \mathrm{~N}$} & \multirow[t]{2}{*}{$\mathrm{P}(\mathrm{ppm})$} & \multirow[t]{2}{*}{$\% \mathrm{OC}$} & \multirow{2}{*}{$\begin{array}{l}\text { Exc. } \\
\text { Acidity } \\
\text { (Cmol } \\
\text { kg-1) }\end{array}$} & \multirow{2}{*}{$\begin{array}{l}\text { Available K } \\
\text { (meq/100g) }\end{array}$} & \multirow{2}{*}{$\begin{array}{l}\text { CEC } \\
(\mathrm{Cmol} \\
\mathrm{kg}-1)\end{array}$} & \multirow{2}{*}{$\begin{array}{l}\text { Bulk } \\
\text { density } \\
(\mathrm{g} / \mathrm{cm} 3)\end{array}$} & \multicolumn{3}{|c|}{ Texture } & \multirow[t]{2}{*}{ Tex. Class } & \multirow{2}{*}{$\begin{array}{l}\text { Soil } \\
\text { Type }\end{array}$} \\
\hline & & & & & & & & \%clay & $\%$ silt & $\%$ sand & & \\
\hline 4.63 & 0.11 & 0.83 & 2.15 & 1.28 & 1.41 & 20.05 & 1 & 45 & 8.75 & 46.25 & $\begin{array}{l}\text { Sandy } \\
\text { clay }\end{array}$ & Nitosol \\
\hline
\end{tabular}

Two types of organic manure (FYM, Compost ) were used in this experiment. Results of manure analysis content were described in Tables 2. The highest levels of $\mathrm{P}(504 \mathrm{ppm})$ was found in Compost manure compared (8.9ppm) to FYM. In contrast, the TN of FYM (5.24\%) higher than the Compost TN $(2.73 \%)$ manure, where Compost manure showed highest $\mathrm{k}(1602 \mathrm{me} / 100 \mathrm{~g})$ concentration than FYM(17.6 me/100 g).

Table 2. N, P and K content of Compost and FYM prepared for the experiment

\begin{tabular}{|c|c|c|c|c|}
\hline Organic source & $\% \mathrm{~B}$ & $\mathrm{P}(\mathrm{ppm})$ & $\mathrm{K}$ (meq/100 g soil) & Total Nitrogen $(\%)$ \\
\hline Compost & 0.27104 & 504 & 1602 & 2.73 \\
\hline FYM & 0.71662 & 8.9 & 17.6 & 5.44 \\
\hline
\end{tabular}

\section{Effect of Inorganic Fertilizers, Manure and Lime Application on the chemical properties of soil}

Soil analysis result for selected physico-chemical properties after harvesting showed that application of organic, inorganic fertilizers and lime significantly affected soil properties such as $\mathrm{pH}$, exchangeable acidity, available phosphorus, total nitrogen , Soil exchangeable potassium, organic carbon content and cation exchange capacity (Table 3). Accordingly, the use of FYM alone, compost alone, $1 / 2$ compost $+\mathrm{NP}, \mathrm{FYM}+$ lime, compost + lime and $1 / 2$ compost $+\mathrm{NP}+$ lime significantly improved soil $\mathrm{pH}$ as compared to other treatments. It is well known that the organic manure and lime applied in acid soil conditions are increasing the degree of base saturation in the same time increasing the buffering capacity of the soil. On this way is possible to avoid unfavorable effect of chemical fertilizers with acid potential. The ameliorating effect of lime on soil acidity has been recorded by Obiri-Nyarko (2012). Continuous addition of FYM along with NPK also increased the soil $\mathrm{pH}$ as compared to the use of NPK alone (Sharma et al. 2013).The increase in soil $\mathrm{pH}$ following of application of manure and lime either sole or combined can be attributed to the release of organic acids (during mineralization of manure), which in turn may have suppressed Al content in the soil through chelation (Onwonga et al., 2008; Okwuagwu et al., 2003). Moreover, lime when applied in the soil reacts with water leading to the production of $\mathrm{OH}$ - ions and $\mathrm{Ca} 2+$ ions which displace 
$\mathrm{H}+$ and $\mathrm{Al} 3+$ ions from soil adsorption sites resulting in an increase in soil $\mathrm{pH}$ (Kisinyo et al., 2012). These findings are similar to those of Adeniyan et al. (2011) and Verde et al. (2013) who found increased soil pH with application of organic fertilizer and lime either sole or combined. However, the use of NP alone, $1 / 2(F Y M+N P), N P+$ lime and $1 / 2(\mathrm{FYM}+\mathrm{NP})+$ lime did not significantly improve soil $\mathrm{pH}$. This might be due to the negative contributions of $\mathrm{N}$ fertilizers to the soil acidity. Generally, treatments that received compost alone and compost with other fertilizer sources significantly lowered exchangeable acidity of the soil (Table 3). Haynes and Molokobate (2001) also reported that the application of organic residues decreased exchangeable acidity and increased the available $\mathrm{P}$ of acidic soils. In contrary, the highest exchangeable acidity was observed from control and recommended NP treatments (Table 3). Except control and FYM + lime, availableP was found to be statistically at par in all treatments. This outcome is in agreement with Poulton et al. (2013) who reported application of organic fertilizer to upper soil surface increases plant available P. Abera et al. (2005) also found higher soil extractable P with higher application of manure. It was also observed that application of compost alone and simultaneously with lime improved CEC and organic carbon stock of the soil.

The combined effect of lime and NP significantly affected $(\mathrm{P}>0.05)$ soil total nitrogen. Compared to the control, all treatments increased in nitrogen content of the soil (Table 3). The highest total $\mathrm{N}$ was obtained from application of integrated lime and recommended NP followed by combined application of 50\% FYM and 50\%NP, $50 \%$ compost and $50 \% \mathrm{NP}$. The total $\mathrm{N}$ increment for the treatments $180 \%, 31 \%, 54 \%$ over the control respectively. whereas, the lowest was obtained from the control treatment (Table 3 . The observed increase in Total $\mathrm{N}$ could be due to some amount of decomposition which might have occurred when compost was added to soil and improvement of the organic matter content of the soil.. This agree with the results reported by Tigist (2017) and Bayu et al. (2017), who reported application of compost and lime on acid soil had significantly increased soil total nitrogen and organic carbon

Application of compost and FYM and their combination with lime showed highly significant effect $(\mathrm{P}<0.01)$ on soil exchangeable $\mathrm{K}$ over the control. Application of lime with compost increased significantly soil exchangeable $\mathrm{K}$ as compared to control treatment (Table 3). This result was in line with Ademba et al (2010) reported significant increase in soil total $\mathrm{P}, \mathrm{K}, \mathrm{Ca}$ and $\mathrm{Mg}$ with sole application of manure, in organic fertilizer and lime. The combination of lime and compost shownt effective increment exchangeable $\mathrm{K}$ by $46 \%$ over the control .This was probably due to the added $\mathrm{K}$ with compost which released into the soil system due to decomposition and mineralization. Kasongo et al. (2013) reported increased soil exchangeable $\mathrm{K}$ when coffee compost was applied to tropical acid soils.

Fertilizers may also cause acidity by increasing the export of basic cations relative to the unfertilized soil (Bolan et al., 1991).In general the highest status of acidity in cultivated land indicates the marked influence of continuous cultivation and removal of basic cations by crop uptake where as the better soil condition on the backyard soil signify the importance of integrated soil fertility management practices.

Table 3. Effect of inorganic and organic fertilizers and lime on chemical properties of soil

\begin{tabular}{|c|c|c|c|c|c|c|c|}
\hline Treatment & $\begin{array}{l}\mathrm{pH} \\
(\mathrm{H} 20)\end{array}$ & $\begin{array}{l}\text { Exc. } \\
\text { Acidity } \\
\text { (Cmol kg- } \\
\text { 1) }\end{array}$ & $\begin{array}{l}\text { Available } \\
\mathrm{P} \\
(\mathrm{mg} \mathrm{kg}-1)\end{array}$ & $\% \mathrm{~N}$ & $\mathrm{OC}(\%)$ & $\begin{array}{l}\text { Available } \\
\text { K } \\
\text { (meq/100g) }\end{array}$ & $\begin{array}{l}\mathrm{CEC} \\
(\mathrm{Cmol} \\
\mathrm{kg}-1)\end{array}$ \\
\hline Control & $4.6 \mathrm{c}$ & $3.4 \mathrm{a}$ & $0.9 \mathrm{bc}$ & $0.13 \mathrm{e}$ & $1.5 \mathrm{~b}$ & $1.37 \mathrm{ef}$ & $35.9 \mathrm{a}$ \\
\hline NP & $4.6 \mathrm{c}$ & $2.9 \mathrm{ab}$ & $1.4 \mathrm{a}$ & $0.18 \mathrm{cde}$ & $1.8 \mathrm{ab}$ & $1.10 \mathrm{f}$ & $27.1 \mathrm{ab}$ \\
\hline FYM & $4.8 \mathrm{ab}$ & $2.5 \mathrm{bc}$ & $1.1 \mathrm{abc}$ & $0.17 \mathrm{de}$ & $1.9 \mathrm{a}$ & $1.62 \mathrm{cde}$ & $29.0 \mathrm{ab}$ \\
\hline Compost & $4.9 \mathrm{a}$ & $1.6 \mathrm{ed}$ & $1.2 \mathrm{abc}$ & $0.20 \mathrm{bcd}$ & $1.8 \mathrm{a}$ & $2.00 \mathrm{a}$ & $34.1 \mathrm{a}$ \\
\hline $1 / 2(\mathrm{FYM}+\mathrm{NP})$ & $4.6 \mathrm{c}$ & $3.0 \mathrm{ab}$ & $1.2 \mathrm{abc}$ & $0.24 \mathrm{ab}$ & $1.7 \mathrm{ab}$ & $1.43 \mathrm{de}$ & $33.3 \mathrm{ab}$ \\
\hline $1 / 2($ compost $+\mathrm{NP})$ & $4.8 \mathrm{ab}$ & $2.0 \mathrm{cde}$ & $1.4 \mathrm{a}$ & $0.23 \mathrm{abc}$ & $1.7 \mathrm{ab}$ & $1.66 \mathrm{~cd}$ & $33.9 \mathrm{a}$ \\
\hline FYM + Lime & $4.8 \mathrm{ab}$ & $2.3 \mathrm{bc}$ & $0.9 \mathrm{bc}$ & $0.17 \mathrm{de}$ & $1.8 \mathrm{a}$ & $1.79 \mathrm{abc}$ & $30.3 \mathrm{ab}$ \\
\hline Compost + lime & $5.0 \mathrm{a}$ & $1.6 \mathrm{e}$ & $1.4 \mathrm{a}$ & $0.17 \mathrm{de}$ & $1.9 \mathrm{a}$ & $1.96 \mathrm{ab}$ & $34.7 \mathrm{a}$ \\
\hline $\mathrm{NP}+$ lime & $4.7 \mathrm{bc}$ & $2.3 \mathrm{bcd}$ & $1.1 \mathrm{abc}$ & $0.27 \mathrm{a}$ & $1.9 \mathrm{a}$ & $1.37 \mathrm{ef}$ & $23.1 \mathrm{~b}$ \\
\hline $1 / 2(F Y M+N P)+$ Lime & $4.7 \mathrm{bc}$ & $2.6 \mathrm{bc}$ & $1.1 \mathrm{abc}$ & $0.20 \mathrm{bcd}$ & $1.9 \mathrm{a}$ & $1.53 \mathrm{cde}$ & $28.4 \mathrm{ab}$ \\
\hline $\begin{array}{l}1 / 2 \text { (compost+ NP }+ \\
\text { lime) }\end{array}$ & $4.8 \mathrm{ab}$ & $2.0 \mathrm{cde}$ & $1.3 \mathrm{ab}$ & $0.21 \mathrm{bcd}$ & $1.9 \mathrm{a}$ & $1.70 \mathrm{bc}$ & $31.5 \mathrm{ab}$ \\
\hline LSD0.05 & 0.2 & 0.7 & 0.4 & 0.0556 & 0.3 & 0.27 & 10.6 \\
\hline CV $(\%)$ & 2.5 & 17.9 & 20.1 & 19.56 & 8.8 & 9.94 & 20.0 \\
\hline
\end{tabular}

Means with in a column with the same letter(s) are not significantly different at 0.05 probability level.

Effect of Soil Amendment on Grain and Biomass yield of maize

The application of soil amendments significantly $(\mathrm{P} \leq 0.05)$ increased maize grainyield and biomass yield in all cropping seasons for all treatments compared to the control. Combined analysis over years indicated that 
recommended NP, 50\% FYM $+50 \% \mathrm{NP}$, recommended $\mathrm{NP}+$ lime and 50\% FYM $+50 \% \mathrm{NP}+50 \%$ lime gave significantly $(\mathrm{P} \leq 0.05)$ superior grain yield of maize as compared to the other organic fertilizers (Table 4). This could be due to the provision of readily available plant nutrients from chemical fertilizers. Application of organic fertilizers along with recommended doses of fertilizers increased the maize productivity to the maximum level, which might be due to the improvement in soil health and release of organic acids that bind aluminum (Al) and iron (Fe), thereby reducing P fixation and increasing its availability (Manjhi et al. 2014). Application of NP, lime and FYM, either alone or in combination, had significant influences on the maize yield. These results are in conformity with the findings of Sharma et al. (2006) and Manoj-Kumar et al. (2012). More over; the result suggests that increasing soil $\mathrm{pH}$ is only partly responsible for improving crop production on acid soils, and organic fertilizer applications promote plant growth by buffering soil acidity and by providing plant-available nutrients. This result was in agreement with Jones et al. (2001) report. The results recommend the use of organic fertilizer alongside with lime and mineral fertilizers to increase maize yields. Similar results reported by Verde et al. (2013) who found that the use of manure alongside with lime and mineral fertilizers to increase soybean yields The high yields observed under combination of manure, NP fertilizer and lime application might be as a result of its ability for improving soil biological and physical properties which increase soil water retention and enhance nutrient uptake (Nwachukwu and Ikeadigh, 2012).

The highest aboveground biomass $(5.91,5.90 \mathrm{t} / \mathrm{ha})$ were observed in $50 \%$ compost $+50 \% \mathrm{NP}+50 \%$ lime, NP $+100 \%$ lime application, respectively(Table 5 ). Among the treatments, the combined application of recommended NP fertilizer and $100 \%$ lime gave the highest reading in harvest index (93.00\%), and also followed by NP (91.5\%), 50\% FYM + 50\% NP + 50\% lime(88.25\%), 50\% FYM + 50\% NP (84\%)and 50\%Compost $+50 \%$ NP (82.25). The result supported by the following work view, poor performance of crop observed could have been due to high soil acidity that fixed nutrients, hence, making them unavailable for plant use. Significantly higher aboveground biomass was recorded under lime+manure+NPK and NPK+lime treatments than under all other treatments. This could be due to the ameliorated soil $\mathrm{pH}$ that encouraged healthy root development with improved uptake of nutrients (Cifu et al., 2004). Addition of lime and manure may have supplied extra $\mathrm{Ca}, \mathrm{Mg}$ and other nutrients that improved further growth (Chimdi et al., 2012).

Table 4..Grain yield of maize (kg ha-1) as influenced by combinations of lime, organic and inorganic fertilizers

\begin{tabular}{|c|c|c|c|c|c|}
\hline \multirow[t]{2}{*}{ Treatment } & \multicolumn{4}{|c|}{ Grain yield (kg ha-1) } & \multirow{2}{*}{$\begin{array}{l}\text { Mean Grain } \\
\text { yield (kg ha-1) }\end{array}$} \\
\hline & 2010 & 2011 & 2013 & 2014 & \\
\hline Control (no amendment) & $2073 d$ & $1764 c$ & $1439 d$ & $2622 \mathrm{e}$ & $1975 f$ \\
\hline Recommended NP & $5083 a$ & $3651 \mathrm{~b}$ & $3191 \mathrm{a}$ & $3820 \mathrm{abc}$ & $3936 \mathrm{ab}$ \\
\hline $100 \%$ FYM & $2527 \mathrm{~cd}$ & $2562 b c$ & $1564 \mathrm{~cd}$ & $2989 \mathrm{de}$ & $2411 \mathrm{ef}$ \\
\hline $100 \%$ compost & 3198bcd & $2564 \mathrm{bc}$ & $1595 \mathrm{~cd}$ & $3722 \mathrm{bcd}$ & 2770de \\
\hline $50 \% \mathrm{FYM}+50 \% \mathrm{NP}$ & $3727 b c$ & $3450 b$ & $2841 \mathrm{ab}$ & $4395 \mathrm{ab}$ & $3603 \mathrm{abc}$ \\
\hline $50 \%$ comp $+50 \% \mathrm{NP}$ & $3319 \mathrm{bcd}$ & $4121 \mathrm{ab}$ & $2690 \mathrm{abc}$ & $4008 \mathrm{ab}$ & $3535 b c$ \\
\hline FYM $+100 \%$ lime & 2790 bcd & $2745 b c$ & $1626 \mathrm{~cd}$ & $3163 \mathrm{cde}$ & 2581def \\
\hline Compost $+100 \%$ lime & $3545 \mathrm{bc}$ & $2633 \mathrm{bc}$ & $2009 \mathrm{bcd}$ & $4173 \mathrm{ab}$ & $3090 \mathrm{~cd}$ \\
\hline $\mathrm{NP}+100 \%$ lime & $3569 \mathrm{bc}$ & $5296 \mathrm{a}$ & $3562 \mathrm{a}$ & $4335 \mathrm{ab}$ & $4191 \mathrm{a}$ \\
\hline $50 \% \mathrm{FYM}+50 \% \mathrm{NP}+50 \%$ lime & $3918 \mathrm{ab}$ & $3202 \mathrm{bc}$ & $2954 \mathrm{ab}$ & $4456 \mathrm{ab}$ & $3633 \mathrm{abc}$ \\
\hline $50 \%$ compost $+50 \% \mathrm{NP}+50 \%$ lime & 3373 bcd & $3613 b$ & $2632 \mathrm{abc}$ & $4538 \mathrm{a}$ & $3539 \mathrm{bc}$ \\
\hline LSD (0.05) & 1333 & 1639 & 1168 & 815 & 641 \\
\hline $\mathrm{CV}(\%)$ & 23.19 & 29.73 & 28.89 & 12.48 & 13.8 \\
\hline
\end{tabular}

Means with in a column with the same letter(s) are not significantly different at 0.05 probability level 
Table 5..Biomass yield of maize (t ha-1) as influenced by combinations of lime, organic and inorganic fertilizers at Jimma

\begin{tabular}{|c|c|c|c|c|c|c|}
\hline \multirow[t]{2}{*}{ Treatment } & \multicolumn{4}{|c|}{ Biomass yield (t ha-1) } & \multirow{2}{*}{$\begin{array}{l}\text { Mean } \\
\text { Biomass } \\
(\mathrm{t} \text { ha-1) }\end{array}$} & \multirow{2}{*}{$\begin{array}{l}\text { Harvest } \\
\text { index } \\
(\%)\end{array}$} \\
\hline & 2010 & 2011 & 2013 & 2014 & & \\
\hline Control (no amendment) & $6.24 \mathrm{c}$ & $4.47 \mathrm{e}$ & $2.00 \mathrm{e}$ & $2.04 \mathrm{e}$ & $3.69 \mathrm{f}$ & $65.5 \mathrm{e}$ \\
\hline Recommended NP & $6.57 \mathrm{bc}$ & $8.16 \mathrm{bc}$ & $2.84 \mathrm{ab}$ & $2.90 \mathrm{ab}$ & $5.12 \mathrm{bc}$ & $91.5 \mathrm{ab}$ \\
\hline $100 \% \mathrm{FYM}$ & $6.76 \mathrm{bc}$ & $6.39 \mathrm{~cd}$ & $2.43 \mathrm{~cd}$ & $2.48 \mathrm{~cd}$ & $4.51 \mathrm{de}$ & $68.25 \mathrm{de}$ \\
\hline $100 \%$ compost & $6.14 \mathrm{c}$ & $7.25 \mathrm{bcd}$ & $2.52 \mathrm{bcd}$ & $2.57 \mathrm{bcd}$ & $4.62 \mathrm{cde}$ & $73.75 \mathrm{cde}$ \\
\hline $50 \% \mathrm{FYM}+50 \% \mathrm{NP}$ & $6.33 c$ & $7.73 \mathrm{bc}$ & $3.08 \mathrm{a}$ & $3.14 \mathrm{a}$ & $5.07 \mathrm{bcd}$ & $84.00 \mathrm{abc}$ \\
\hline $50 \%$ comp $+50 \% \mathrm{NP}$ & $6.59 \mathrm{bc}$ & $9.00 \mathrm{ab}$ & $2.84 \mathrm{ab}$ & $2.90 \mathrm{ab}$ & $5.33 \mathrm{~b}$ & $82.25 \mathrm{abcd}$ \\
\hline FYM $+100 \%$ lime & $7.26 \mathrm{abc}$ & $5.57 \mathrm{de}$ & $2.25 \mathrm{de}$ & $2.29 \mathrm{de}$ & $4.34 \mathrm{e}$ & $74.25 \mathrm{cde}$ \\
\hline Compost $+100 \%$ lime & $8.15 \mathrm{a}$ & $5.65 \mathrm{de}$ & $2.82 \mathrm{abc}$ & $2.87 \mathrm{abc}$ & $4.87 \mathrm{bcde}$ & $76.50 \mathrm{bcde}$ \\
\hline $\mathrm{NP}+100 \%$ lime & 7.79ab & $10.09 \mathrm{a}$ & $2.85 \mathrm{ab}$ & $2.91 \mathrm{ab}$ & $5.91 \mathrm{a}$ & $93.00 \mathrm{a}$ \\
\hline $50 \% \mathrm{FYM}+50 \% \mathrm{NP}+50 \%$ lime & $5.97 \mathrm{c}$ & $7.75 \mathrm{bc}$ & $2.98 \mathrm{a}$ & $3.04 \mathrm{a}$ & $4.93 \mathrm{bcd}$ & $88.25 \mathrm{abc}$ \\
\hline $\begin{array}{l}50 \% \text { compost }+50 \% \mathrm{NP}+50 \% \\
\text { lime }\end{array}$ & $7.05 \mathrm{abc}$ & $10.05 \mathrm{a}$ & $3.22 \mathrm{a}$ & $3.29 \mathrm{a}$ & $5.90 \mathrm{a}$ & $76.00 \mathrm{bcde}$ \\
\hline $\operatorname{LSD}(0.05)$ & 1.36 & 1.83 & 0.41 & 0.42 & 0.57 & 15.67 \\
\hline $\mathrm{CV}(\%)$ & 11.74 & 14.1 & 8.77 & 8.81 & 6.75 & 13.66 \\
\hline
\end{tabular}

Means with in a column with the same letter(s) are not significantly different at 0.05 probability level

\section{Conclusion}

The use of compost, manure and lime directly and indirect improving soil chemical and physical properties. provide significant quantities of available nitrogen, $\mathrm{P}, \mathrm{Mo}$ and $\mathrm{B}$, and more favorable conditions for microbial mediated reactions such as nitrogen fixation and nitrification.

Integrate use of lime, organic nutrient sources and inorganic fertilizers are beneficial in improving maize productivity and ameliorating properties of acid soil over the use of these components individually. Lime, organic nutrient sources and inorganic fertilizers are important component of integrated acid soil management. The result showed that organic fertilizers are more effective after the year of cropping.

Application of inorganic fertilizer plus manure and lime for mize cultivation significantly increased the grain nutrient level. The level of $\mathrm{P}$ in maize grain increased more with the application of inorganic fertilizer + lime and manure. From the above concluding remarks of the present study it could be suggested that the farmer(s) of our country can be applied organic manure or lime along with 50\% NPKS for enhancing the production of maize in acidic red soil.

This acidification process and depletion of basic cations lead to the increase threat to agricultural productivity in the study area. Therefore, the study emphasis that soil acidity problem is critical and needs immediate intervention to amend the soil for crop production and sustainability of soil productivity. OM in the form of farmyard manure/compost is vital to add on farm land and adopt techniques by applying lime to neutralize the acidity. Indigenous practices such as traditional agro forestry, composting, crop rotation, biomass transfer, etc. and improved practices integrated with findings of more research work on nutrient management for sustainable agricultural development in the region.

\section{References}

Abera T, D Feyissa, and H Husuf .2005. Effects of inorganic and organic fertilizers on grain Yield of maizeclimbing beans intercropping and soil fertility in Western Oromiya, Ethiopia. Paper presented in a conference on International Agricultural research for Development.

Adeniyan ON, AO Ojo, OA kinbode, and JA Adediran . 2011. Comparative study of different organic manures and NPK fertilizer for improvement of soil chemical properties and dry matter yield of maize in two different soils. J. Soil Sci. Env. Manag., 2(1): 9-13.

Agegnehu, G., and Amede, T. (2017). Integrated soil fertility and plant nutrient management in tropical agroecosystems: A review. Pedosphere 27, 662-680.

Amoah, A.A., M. Senge, S. Miyagawa and K. Itou, 2012. Effects of soil fertility management on growth, yield and water-use efficiency of maize (Zea mays L.) and selected soil properties. Commun. Soil Sci. Plant Anal., 43: 924-935.

Asrat, M., Gebrekidan, H., Yli-Halla, M., Bedadi, B. and Negassa, W., 2014. Effect of integrated use of lime, manure and mineral $P$ fertilizer on bread wheat (Triticum aestivum) yield, uptake and status of residual soil P on acidic soils of Gozamin District, north-western Ethiopia. Agriculture, Forestry and Fisheries, 3(2), 7685. 
Ayodele O. J and O. S. Shittu, 2014. Fertilizer, Lime and Manure Amendments for Ultisols Formed on Coastal Plain Sands of Southern Nigeria. Journal of Agriculture, Forestry and Fisheries3(6):481-488.

Bayu Dume, Dejene Ayele, Alemayehu Regassa and Gezahegn Berecha.2017. Improving available phosphorus in acidic soil using biochar at Dedesa district Illu Ababora Zone, Southwest Ethiopia. Journal of Soil Science and Environmental Management. 8(4): 87-94.

Bilalis, D., A. Karkanis, A. Efthimiadou, A. Konstantas and V. Triantafyllidis, 2009. Effects of irrigation system and green manure on yield and nicotine content of Virginia (flue-cured) organic tobacco (Nicotiana tabaccum), under Mediterranean conditions. Ind. Crops Prod., 29: 388-394.

Bokhtiar, S.M. and K. Sakurai, 2005. Effects of organic manure and chemical fertilizer on soil fertility and productivity of plant and ratoon crops of sugarcane. Arch. Agron. Soil Sci., 51: 325-334.

Bolan,N.S.,M.J.Hedley, and R.E.White.1991.Process of soil acidification during nitrogen cycling with emphasis on legume based pastures. Plant and soil 134:53-63

Bray RH and LT Kurtz. 1945. Determination of total, organic, and available forms of phosphorus insoil.SoilSci.59:39-45

Brook, R. H. 1983. International course on soil and plant analysis: Lecture notes. Service Laboratory for Soil, Plant and Water Analysis, Soil Science Department, Faculty of Agriculture, Minia University, Egypt

Cifu, M., Xiaonan, L., Zhihong, C., Zhengyi, H., \& Wanzhu, M. (2004). Long-term effects of lime application on soil acidity and crop yields on a red soil in Central Zhejiang. Plant and Soil, 265(1-2), 101109.https://doi.org/10.1007/s11104-005-8941-y

Chapman HD. 1966. Diagonestic criteria for plant and soils University of California press. Food and Agricultural Organization . 2011. World Agricultural Production. [Online] Available at: http://faostat.fao.org/default.aspx.

Chimdi, A., Gebrekidan, V., Kibret, K., \& Tadesse, A. (2012). Effects of Liming on Acidity-Related Chemical Properties of Soils of Different Land Use Systems in Western Oromia, Ethiopia. World Journal of Agricultural Sciences, 8(6), 560-567

Fageria, N., and Baligar, V. (1997). Integrated plant nutrient management for sustainable crop production-an overview. Int. J. Trop. Agric. 15, 1-18.

Fageria, N.K. and V.C. Baligar, 2008. Ameliorating soil acidity of tropical oxisols by liming for sustainable crop production. Advance in Agronomy, 99: 345 - 400. FAO (2014). Analysis of price incentives for wheat in Ethiopia. FAO, Rome, Italy

Farina, M.P.W. 1999 Technical Report on Soil Test Calibration in Ethiopia. Ministry of Agriculture, Addis Ababa, Ethiopia. 60p.

Foth, H.D. and B.G. Ellis., 1997. Soil fertility, 2nd Ed. Lewis CRC Press LLC., USA. 290p.

Haile, H., Asefa, S., Regassa, A., Demssie, W., Kassie, K., and Gebrie, S. (2017). Extension manual for acid soil management (unpublished report). (A. T. A. (ATA), ed.), Addis Ababa, Ethiopia.

Haynes RJ and MS Mokolobate. 2001. Amelioration of Al toxicity and P deficiency in acid soils by additions of organic residues: a critical review of the phenomenon and the mechanisms involved. Nutrient Cycling in Agro ecosystems (59): 47-63

Jones, B. J. Jr. 2001. Laboratory guides for conducting soil tests and plant analysis, CRC press, London.

Kasongo, R. K., A. Verdoodt, P. Kanyankogote, G. Baert, \&E.Van Ranst. 2013. Response of Italian Ryegrass (Lolium Multiflorum Lam.) to Coffee Waste Application on a Humid Tropical Sandy Soil. Soil Use and Management, 29: 22-29.

Kiani, M.J., M.K. Abbasi and N. Rahim, 2005. Use of organic manure with mineral $N$ fertilizer increases wheat yield at Rawalakot Azad Jammu and Kashmir. Arch. Agron. Soil Sci., 51: 299-309.

Kisinyo PO, SO Gudu, CO Othieno, JR Okalebo, PA Opala, JK Maghanga, DW Agalo, WK Ng'etich, JA Kisinyo, RJ Osiyo, AO Nekesa, ET Makatiani, DW Odee, and BO Ogola. 2012. Effects of lime, phosphorus and rhizobia on Sesbaniasesban performance in a Western Kenyan acid soil. Africa. J. Agric. Res., 7(18): 2800280.

Kochian L.V., O.A. Hoekenga and M.A. Pineros, 2004. How do crop plants tolerate acid soils mechanisms of aluminum tolerance and phosphorous efficiency? Annual Review of Plant Biology, 55: 459 - 493.

Landon, J.R. 1991. Booker tropical soil manual: A Handbook for Soil Survey and Agricultural Land Evaluation in the Tropics and Subtropics. Longman Scientific and Technical, Essex, New York. 474p.

Manjhi RP, MS Yadav, and R Thakur. 2014. Effect of integrated nutrient management on crop productivity and changes in soil fertility in maize (Zea mays)-wheat (Triticum aestivum) cropping sequence. Indian Journal of Agronomy. 59:371-76

Manoj-Kumar S, BU Hazarika, T Choudhury, BC Ramesh, LJ Verma, and Bordoloi. 2012. Liming and Integrated Nutrient Management for Enhancing Maize Productivity on Acidic Soils of Northeast India. Indian Journal of Hill Farming 25(1):35-37

McLean, E.O. 1965. Aluminum. pp. 978-998. In: C.A. Black (Ed.). Methods of Soil Analysis. Agron. No.9. Part II. Am.Soc.Agron, Madison, Wisconsin. USA Nwachukwu OI and Ikeadigh MC . 2012. Water Use Efficiency 
and Nutrient Uptake of Maize as Affected By Organic and Inorganic Fertilizer. PAT, 8(1): 199-208.

Obiri-Nyarko F. 2012. Ameliorating soil acidity in Ghana: A concise review of approaches. ARPN Journal of Science and Technology. 2012; 2:143-153.

Okwuagwu MI, ME Alleh, and IO Osemwota . 2003. The effects of organic and inorganic manure on soil properties and yield of okra in Nigeria. Afric. Crop Sci. Confer. Proc., 6:390-393.

Onwonga RN, JJ Lelei, B Freyer, JK Friedel, SM Mwonga, and P Wandhawa .2008. Low cost technologies for enhance $\mathrm{N}$ and $\mathrm{P}$ availability and maize (Zea mays L.) performance on acid soils.WorldJ.Agric.Sci.,4(5):862873.

Paulos Dubale (ed). 1994. Mineral fertilization of coffee in Ethiopia. Institute of Agricultural Research, Addis Ababa.

Poulton PR, AE Johnston and RP White. 2013. Plant-available soil phosphorus. Part I: the response of winter wheat and spring barley to Olsen P on a silty clay loam. Soil use and management (29) 4-11.

SAS Institute. 2008. SAS Version 9.1, 2007-2008. SAS Institute, Inc., Carry, NC.

Sharma GD, R Thakur, S Raj, DL Kauraw, and PS Kulhare. 2013. Impact of integrated nutrient management on yield, nutrient uptake, protein content of wheat (Triticum aestivum) and soil fertility in a typic haplustert. The Biosacn. 8:1159-1164.

Sharma PD, TC Baruah, AK Maji, and Patiram. 2006. Management of acid soils in NEH Region, Natural Resource Management Division (ICAR), Krishi Anusandhan BhawanII, Pusa Campus, New Delhi. Technical Bulletin, pp 14.

Tekalign Mamo and I. Haque. 1991. Phosphorus status of some Ethiopian soils. III, Evaluation of soil test methods for available phosphorus. Tropical Agriculture 68: 51-56

Tigist Adisu Legesse.2017.Soybean (Glycine max L.) Response to Lime and Vermicompost Amelioration of Acidic Nitisols of Assosa, North Western Ethiopia. A Thesis Submitted to the School of Natural Resources Management and Environmental Sciences, Postgraduate Program Directorate, Haramaya University.89pp.

Tolessa Debelle, Tesfa Bogale, Wakene Negassa, Tenaw Worayehu, Minale Liben, Tewodros Mesfin, Birtukan Mekonen and Waga Mazengia. 2001. A review of fertilizer management research on maize in Ethiopia: Enhancing the contribution of maize to food security in Ethiopia, Proceedings of the second National maize workshop of Ethiopia .12-16 November 2001, Addis Ababa, Ethiopia. pp.46-55.

Van Reedwijk LP .1992. Procedure for soil analysis. 3rd Edition. International Soil Reference and information Center Wagenigen (ISRIC). The Netherelands. P.O.Box 353. 6700 AJ Wagenigen.

Verde Benvindo Serafim, Danga Benjamin Oginga, and Mugwe Jayne Njeri. 2013. Effects of manure, lime and mineral $\mathrm{P}$ fertilizer on soybean yields and soil fertility in a humic nitisol in the Central Highlands of Kenya. International Journal of Agricultural Science Research Vol. 2(9), pp. 283-291.

Walkely A and IA Black. 1934. An examination of the Degtjareff method for determination of soil organic matter and a proposal modification of the chronic acid titration method.

Wakene Negassa, 2001. Assessment of important physicochemical properties of Dystric Udalf (Dystric Nitosols) under different management systems in Bako area, western Ethiopia. M.Sc. Thesis Submitted to School of Graduate Studies, Alemaya University, Ethiopia. 93p.

Zeleke, G., Agegnehu, G., Abera, D., and Rashid, S. (2010). Fertilizer and soil fertility potential in Ethiopia: Constraints and opportunities for enhancing the system. (I. F. P. R. I. (IFPRI), ed.), pp. 63, Washington, DC, USA 